Crude Politics 
This page intentionally left blank 


\section{Crude Politics}

The California Oil Market, I900-I940

\section{Paul Sabin}


University of California Press

Berkeley and Los Angeles, California

University of California Press, Ltd.

London, England

(C) 2005 by the Regents of the University of California

Library of Congress Cataloging-in-Publication Data

Sabin, Paul, I970-.

Crude politics : the California oil market, r900-I940 / Paul Sabin.

p. $\mathrm{cm}$.

Includes bibliographical references and index.

ISBN 0-520-24I98-3 (alk. paper).

I. Petroleum industry and trade-Political aspectsCalifornia-History-2oth century. 2. Petroleum industry and trade-Government policy-CaliforniaHistory-2oth century. 3. Energy policy-United States-History-2oth century. I. Title.

HD9567.C2 332005

$338.2^{\prime} 7282^{\prime} 097940904 \mathrm{I}-\mathrm{dc2} 2$

2004008524

Manufactured in the United States of America
$\begin{array}{lllllllll}\text { I3 } & \text { I2 } & \text { II } & \text { IO } & 09 & 08 & 07 & 06 & 05\end{array}$

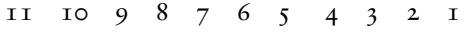

The paper used in this publication meets the minimum requirements of ANSI/NISO Z39.48-I992 (R I997)

(Permanence of Paper).@ 
For Emily 
This page intentionally left blank 
Any estimate of future supply and demand that did not embrace the price factor would be futile. Price finds the oil and produces it. Price controls and limits its use.

Charles Evans Hughes, former secretary of state and U.S. Supreme Court justice, 1926

Renewables are now generally costlier than fossil fuels.... Government policies should support long-term research on alternatives but let the marketplace decide which technical approach will gain commercial and consumer acceptance.

ExxonMobil op-ed advertisement, 200I 
This page intentionally left blank 